\title{
EFISIENSI PENGGUNAAN INPUT PADA USAHATANI KAKAO DI DESA KELE'I KECAMATAN PAMONA TIMUR KABUPATEN POSO
}

\author{
Marianne Reynelda Mamondol ${ }^{1^{*}}$ dan Nimrod Balingki ${ }^{2}$ \\ ${ }^{1,2}$ Program Studi Agribisnis Fakultas Pertanian Universitas Kristen Tentena \\ *E-mail korespondensi : mariannemamondol@unkrit.ac.id
}

\begin{abstract}
ABSTRAK
Penelitian ini bertujuan untuk mengetahui : (1) pengaruh luas lahan, tenaga kerja, pupuk Phonska, SP 36, dan Urea terhadap produksi kakao, (2) skala usahatani kakao, dan (3) efísiensi penggunaan input lahan, tenaga kerja, dan pupuk Phonska, SP 36, dan Urea pada usahatani kakao di Desa Kele'i Kecamatan Pamona Timur Kabupaten Poso. Populasi penelitian ialah 30 orang petani kakao di Desa Kele'i yang keseluruhannya dijadikan sebagai responden penelitian. Data dikumpulkan melalui pengisian kuisioner dan wawancara terhadap responden penelitian. Data dianalisis dengan menggunakan analisis fungsi produksi Cobb-Douglas, skala usaha (return to scale), dan efisiensi penggunaan input dengan indikator berupa Nilai Produk Marginal (NPM) dan rasio NPM-HI (Harga Input). Hasil penelitian menunjukkan bahwa luas lahan, pupuk SP 36, dan Urea berpengaruh positif dan signifikan terhadap produksi kakao. Usahatani kakao berada pada skala hasil meningkat (increasing return to scale). Penggunaan input lahan, pupuk SP 36 dan Urea belum efisien dan masih dapat ditambahkan untuk meningkatkan produksi dan pendapatan petani kakao.
\end{abstract}

Keywords : efisiensi, input, produksi kakao, lahan, pupuk

\section{PENDAHULUAN}

Kakao (Theobroma cacao L.) merupakan salah satu komoditas tanaman perkebunan andalan Provinsi Sulawesi Tengah yang berperan penting dalam perekonomian daerah, yaitu sebagai sumber pendapatan dan penyedia lapangan pekerjaan bagi masyarakat. Sulawesi Tengah merupakan salah satu pemasok utama biji kakao secara nasional, yaitu sekitar $19 \%$ dari total produksi kakao Indonesia (Yantu et al, 2011). Biji kakao yang diperdagangkan di pasar domestik dan internasional merupakan sumber devisa yang cukup besar bagi daerah.

Tabel 1. Volume dan Nilai Ekspor Biji Kakao Sulawesi Tengah Tahun 2009 - 2015

\begin{tabular}{ccc}
\hline Tahun & Volume Ekspor (ton) & Nilai Ekspor (juta US\$) \\
\hline 2009 & $92.185,00$ & 228,313 \\
2010 & $109.511,52$ & 294,375 \\
2011 & $45.218,22$ & 126,674 \\
2012 & $36.870,00$ & 82,300 \\
2013 & $20.750,00$ & 46,200 \\
2014 & 570,00 & 1,644 \\
2015 & $1.000,00$ & 2,545 \\
\hline
\end{tabular}

Sumber : BPS Sulteng, 2017 
Berdasarkan data BPS, Kabupaten Poso sejak tahun 2011 hingga 2016 merupakan penghasil kakao terbesar kedua di Sulawesi Tengah setelah Kabupaten Parigi Moutong. Data perkembangan luas areal dan produksi kakao Kabupaten Poso diperlihatkan pada tabel berikut.

Tabel 2. Luas Areal, Produksi, dan Produktivitas Kakao Kabupaten Poso dan Provinsi

\begin{tabular}{ccccccc}
\multicolumn{7}{c}{ Sulawesi Tengah Tahun 2009-2016 } \\
\hline Tahun & $\begin{array}{c}\text { Luas Areal } \\
\text { (ha) }\end{array}$ & $\begin{array}{c}\text { Produksi } \\
\text { Kab. Poso } \\
\text { (ton) }\end{array}$ & $\begin{array}{c}\text { Produksi } \\
\text { Sulteng } \\
\text { (ton) }\end{array}$ & $\begin{array}{c}\text { \% } \\
\text { Kontribusi }\end{array}$ & $\begin{array}{c}\text { Produktivitas } \\
\text { Kab. Poso } \\
\text { (ton/ha) }\end{array}$ & $\begin{array}{c}\text { Produktivitas } \\
\text { Sulteng } \\
\text { (ton/ha) }\end{array}$ \\
\hline 2009 & 28.646 & 35.793 & 212.073 & 16,88 & 1,25 & 1,27 \\
2010 & 36.168 & 28.646 & 186.875 & 15,33 & 0,79 & 1,12 \\
2011 & 26.827 & 27.739 & 168.859 & 16,43 & 1,03 & 0,86 \\
2012 & 40.740 & 28.366 & 181.523 & 15,63 & 0,70 & 0,61 \\
2013 & 40.529 & 32.469 & 195.846 & 16,58 & 0,80 & 0,69 \\
2014 & 40.689 & 34.532 & 208.435 & 16,57 & 0,85 & 0,72 \\
2015 & 39.103 & 19.149 & 146.507 & 13,07 & 0,50 & 0,51 \\
2016 & 39.209 & 25.639 & 168.734 & 15,19 & 0,65 & 0,58 \\
\hline
\end{tabular}

Sumber : BPS Sulteng, 2017

Data pada tabel menunjukkan bahwa luas areal, produksi, maupun produktivitas kakao di Kabupaten Poso mengalami fluktuasi dari tahun ke tahun. Selama kurun waktu 2009 hingga 2016, rata-rata luas areal penanaman kakao ialah 36.489 ha, rata-rata produksi sebesar 29.042 ton, dan rata-rata produktivitas sebesar 0,82 ton/ha. Angka tersebut lebih besar jika dibandingkan dengan rata-rata produktivitas kakao Sulawesi Tengah sebesar 0,80 ton/ha, namun lebih rendah bila dibandingkan dengan potensi produktivitas kakao yang bisa mencapai 2 hingga 2,5 ton/ha/tahun (Tahir dan Fadwiwati 2015).

Di Sulawesi Tengah, produksi kakao $100 \%$ merupakan hasil dari perkebunan rakyat (smallholder), yang umumnya banyak mengalami kendala teknis dan non teknis dalam pengembangannya. Beberapa faktor yang mempengaruhi rendahnya produktivitas kakao menurut Tahir et al (2015) ialah umur tanaman yang relatif tua (25 tahun) yang produksinya hanya setengah dari potensi produksi, tingginya intensitas serangan hama penggerek buah kakao (PBK) dan penyakit Vascular Streak Dieback (VSD) atau penyakit mati pucuk, dan belum banyak dimanfaatkannya bahan tanam unggul kakao lokal sebagai sumber bibit unggul spesifik lokasi. Pradnyani dan Indrajaya (2014) mengemukakan bahwa produktivitas kakao yang rendah pada perkebunan rakyat juga disebabkan oleh tingkat pengetahuan dan penguasaan teknologi yang masih kurang pada petani kakao, keterbatasan modal, lahan garapan yang sempit, dan kurangnya keterampilan yang dimiliki petani dalam melakukan pemeliharaan pada tanaman. Sedangkan menurut Dewi (2012), rendahnya produktivitas kakao disebabkan karena petani kurang termotivasi menerapkan teknologi sesuai anjuran akibat harga jual kakao yang relatif rendah yang mengakibatkan rendahnya pendapatan petani. Pendapatan petani yang tidak memadai membuat petani tidak mampu membiayai tenaga kerja dan sarana produksi lain seperti pupuk dan pestisida yang cenderung semakin meningkat harganya (Antara dan Effendy 2009).

Usahatani kakao skala besar dan bersifat komersil umumnya telah memperhitungkan perbandingan antara biaya yang dikeluarkan dengan pendapatan yang diperoleh, karena biaya 
produksi berperan penting dalam menentukan besarnya pendapatan. Jadi pengukuran efisiensi diperlukan untuk mengetahui sampai sejauh mana setiap unit biaya yang dikorbankan mampu memberikan pendapatan bagi produsen (Pradnyani dan Indrajaya 2014). Menurut Hanafie (2010), pengertian efisiensi dalam usahatani terkait dengan masalah apakah usahatani yang dilakukan mendapatkan keuntungan atau tidak, sehingga usahatani dikatakan menguntungkan apabila apabila setiap tambahan nilai output (produksi) selalu lebih besar daripada setiap tambahan input (faktor produksi) yang digunakan. Farrel (1957) dalam Saptana (2012) mengemukakan konsep efisiensi yang meliputi : (1) efisiensi teknis, yaitu kemampuan petani selaku produsen mendapatkan output maksimum dari penggunaan sekumpulan input, (2) efisiensi alokatif atau efisiensi harga, yaitu kemampuan petani untuk menggunakan input pada proporsi yang optimal pada harga-harga input dan teknologi produksi yang tetap, dan (3) efisiensi ekonomi, merupakan gabungan efisiensi teknis dan alokatif, di mana output yang dihasilkan efisien secara teknis maupun alokatif.

Hasil penelitian Yani et al (2017) menunjukkan bahwa produksi kakao di Kecamatan Bandar Baru Kabupaten Pidie Jaya, Nanggroe Aceh Darussalam (NAD) dipengaruhi oleh faktor-faktor berupa luas lahan, modal, serta hama dan penyakit tanaman. Efisiensi faktor produksi yang bernilai rata-rata lebih dari 1 menunjukkan penggunaan yang belum efisien dan masih dapat ditingkatkan untuk memperbesar produksi dan pendapatan. Alkamalia et al (2017) melaporkan bahwa secara keseluruhan untuk wilayah Provinsi (NAD), faktor luas lahan dan tenaga kerja secara serempak berpengaruh signifikan terhadap produksi kakao. Penelitian oleh Rinaldi et al (2013) memperlihatkan bahwa faktor yang mempengaruhi secara positif produksi kakao pada perkebunan rakyat di Bali ialah tenaga kerja, pestisida, dan luas lahan, di mana tenaga kerja menjadi variabel yang paling responsif. Sarini (2017) mengemukakan bahwa produksi kakao di Desa Dolago Kecamatan Parigi Selatan Kabupaten Parigi Moutong, Sulawesi Tengah dipengaruhi oleh jumlah pohon kakao, pupuk Urea, pupuk NPK, dan tenaga kerja. Penggunaan pupuk belum efisien dan masih dapat ditambah, sebaliknya jumlah tenaga kerja tidak efisien dan perlu dikurangi. Sedangkan penelitian Tangku et al (2015) menunjukkan pengaruh positif luas lahan, pupuk, tenaga kerja, dan pestisida terhadap produksi kakao di Desa Kawende Kecamatan Poso Pesisir Utara Kabupaten Poso. Penggunaan lahan, pupuk, dan pestisida belum efisien sementara penggunaan tenaga kerja tidak efisien.

Kecamatan Pamona Timur di Kabupaten Poso merupakan salah satu wilayah penghasil kakao dengan luas areal sebesar 1.175 ha (BPS Poso 2017). Desa Kele'i di Kecamatan Pamona Timur memiliki areal penanaman kakao seluas 65 ha dengan jumlah petani kakao sebanyak 30 orang. Adapun produktivitas kakao rata-rata di Desa Kele'i ialah 0,4 ton/ha, lebih rendah dibandingkan dengan produktivitas kakao Kabupaten Poso. Hasil survei pendahuluan memperlihatkan bahwa lahan, tenaga kerja, dan pupuk berupa Phonska, Urea, dan SP 36 merupakan input yang sangat dibutuhkan oleh petani setempat untuk melaksanakan proses produksi kakao. Karena itu dibutuhkan penelitian untuk mengetahui tingkat efisiensi penggunaan input-input yang dimaksud agar petani dapat meningkatkan produktivitas dan pendapatannya dari berusahatani kakao. Tujuan dilakukannya penelitian ini ialah untuk mengetahui : (1) pengaruh luas lahan, jumlah tenaga kerja, dosis pupuk Phonska, SP 36, dan Urea terhadap produksi kakao, (2) skala usahatani kakao di Desa Kele'i, dan (3) efisiensi penggunaan input lahan, tenaga kerja, dan pupuk pada usahatani kakao di Desa Kele'i. 


\section{METODE}

Penelitian ini dilaksanakan pada bulan Mei hingga Juli 2018 di Desa Kele'i Kecamatan Pamona Timur Kabupaten Poso. Populasi penelitian ialah petani kakao berjumlah 30 orang yang keseluruhannya dijadikan sebagai responden penelitian. Data yang dikumpulkan ialah data primer dari responden berupa luas lahan yang diusahakan untuk penanaman kakao, jumlah tenaga kerja, serta dosis pupuk Phonska, SP 36, dan Urea yang digunakan. Data sekunder berupa data dari Badan Pusat Statistik Provinsi Sulawesi Tengah dan Kabupaten Poso mengenai luas areal penanaman, produksi, volume, dan nilai ekspor kakao. Data primer dikumpulkan melalui pengisian kuisioner dan wawancara dengan responden, sedangkan data sekunder dikumpulkan melalui studi pustaka.

Data primer yang terkumpul selanjutnya dianalisis dengan menggunakan analisis fungsi produksi Cobb-Douglas untuk mengetahui input-input $\left(\mathrm{X}_{\mathrm{i}}\right)$ yang berpengaruh terhadap produksi kakao (Y). Model yang digunakan ialah :

$$
\mathrm{Y}=\mathrm{a} \mathrm{a} X_{1}^{b_{1}} X_{2}{ }^{b_{2}} X_{\mathrm{a}}{ }^{b_{4}} X_{4}{ }^{b_{4}} X_{5}{ }_{5}^{b_{5}} \mathrm{e}
$$

Guna memudahkan pendugaan maka persamaan tersebut diubah ke dalam bentuk fungsi regresi linear berganda sebagai berikut :

$$
\mathrm{Y}=\mathrm{a}+\mathrm{b}_{1} \log \mathrm{X}_{1}+\mathrm{b}_{2} \log \mathrm{X}_{2}+\mathrm{b}_{3} \log \mathrm{X}_{3}+\mathrm{b}_{4} \log \mathrm{X}_{4}+\mathrm{b}_{5} \log \mathrm{X}_{5}+\mathrm{e}
$$

di mana :

$\mathrm{Y}=$ produksi kakao

$\mathrm{a}=$ konstanta

$\mathrm{b}_{1}=$ koefisien regresi variabel $\mathrm{X}_{1}$

$\mathrm{X}_{1}=$ luas lahan

$\mathrm{b}_{2}=$ koefisien regresi variabel $\mathrm{X}_{2}$

$\mathrm{X}_{2}=$ jumlah tenaga kerja

$\mathrm{b}_{3}=$ koefisien regresi variabel $\mathrm{X}_{3}$

$\mathrm{X}_{3}=$ pupuk Phonska

$\mathrm{b}_{4}=$ koefisien regresi variabel $\mathrm{X}_{4}$

$\mathrm{X}_{4}=$ pupuk SP 36

$\mathrm{b}_{5}=$ koefisien regresi variabel $\mathrm{X}_{5}$

$\mathrm{X}_{5}=$ pupuk Urea

e $=$ error term

Signifikansi koefisien regresi diuji melalui perbandingan antara nilai signifikansi hasil perhitungan (sig value) dengan nilai signifikansi tetapan sebesar 0,05 , di mana koefisien regresi signifikan apabila sig $<0,05$. Koefisien regersi pada model berfungsi pula sebagai angka elastisitas input yang menggambarkan tingkat sensitivitas produksi sebagai akibat perubahan penggunaan input sebesar $1 \%$. Pengujian pengaruh simultan input lahan, tenaga kerja, pupuk Phonska, SP 36, dan Urea terhadap produksi kakao dilakukan melalui uji F, dengan patokan apabila F hitung $<$ signifikansi 0,05 maka nilai F dinyatakan signifikan. Nilai kesesuaian model (goodness of fit) dinyatakan dalam koefisien determinasi R2 yang menunjukkan seberapa besar variabel dependen (Y) dipengaruhi oleh variabel-variabel independen (X) pada model. Untuk menentukan skala usaha (Return to Scale / RTS) digunakan rumus :

$$
\text { RTS }=b_{1}+b_{2}+b_{3}+b_{4}+b_{5}
$$


Nilai RTS $<1$ menunjukkan skala usaha menurun (decreasing return to scale), nilai RTS $=1$ menunjukkan skala usaha konstan (constant return to scale), sedangkan nilai RTS $>1$ menggambarkan skala usaha meningkat (increasing return to scale).

Efisiensi penggunaan input dihitung dengan menggunakan indikator Nilai Produk Marginal (NPM), yaitu nilai yang meningkatkan output (Y) dari penambahan unit input $(\mathrm{X})$ apabila $\mathrm{Y}$ dijual dengan harga tetap (Mahabirama et al 2013). Efisiensi tercapai apabila NPM sama dengan harga input (HI). NPM ditentukan melalui persamaan matematika :

di mana :

$$
\mathrm{NPM}=\frac{\text { b. Y. } \mathrm{P}_{\mathbf{y}}}{\mathrm{X}}
$$

$$
\begin{aligned}
\mathrm{NPM} & =\text { nilai produk marginal } \\
\mathrm{b} & =\text { elastisitas input } \\
\mathrm{Y} & =\text { produksi kakao } \\
\mathrm{Py} & =\text { harga biji kakao } \\
\mathrm{X} & =\text { jumlah faktor produksi }
\end{aligned}
$$

Rasio NPM/HI > 1 menunjukkan bahwa penggunaan input dianggap belum efisien sehingga masih dapat ditambah penggunaannya untuk memperbesar pendapatan. Rasio NPM/HI $=1$ menunjukkan bahwa penggunaan input efisien, sedangkan rasio NPM/HI $<1$ menunjukkan bahwa penggunaan input tidak efisien atau berlebihan sehingga perlu dikurangi.

\section{HASIL DAN PEMBAHASAN}

\section{Pengaruh Input Terhadap Produksi Kakao}

Hasil pendugaan pengaruh input terhadap produksi kakao diperlihatkan pada tabel sebagai berikut.

Tabel 3. Pendugaan Fungsi Produksi Cobb-Douglas Usahatani Kakao di Desa Kele'i Tahun 2018

\begin{tabular}{lccccc}
\hline \multicolumn{1}{c}{ Variabel } & Koefisien & Standar Error & $\mathrm{p}$ & sig & Keterangan \\
\hline Konstanta & 1,002253 & 0,228979 & 0,000 & & \\
Luas Lahan $\left(\mathrm{X}_{1}\right)$ & 0,445928 & 0,148998 & 0,006 & 0,050 & Signifikan \\
Tenaga Kerja $\left(\mathrm{X}_{2}\right)$ & 0,170551 & 0,173647 & 0,336 & & Tidak signifikan \\
Pupuk Phonska & 0,099863 & 0,101822 & 0,336 & & Tidak signifikan \\
$\left(\mathrm{X}_{3}\right)$ & 0,302003 & 0,130313 & 0,029 & & Signifikan \\
Pupuk SP 36 $\left(\mathrm{X}_{4}\right)$ & 0,350339 & 0,102612 & 0,002 & & Signifikan \\
Pupuk Urea $\left(\mathrm{X}_{5}\right)$ & & & & & \\
\hline $\mathrm{R}^{2}=81,74 \%$ & & & & \\
F val. $=0,000$ & & & & & \\
\hline
\end{tabular}

Sumber : Data primer (diolah), 2018

Hasil analisis regresi dengan fungsi produksi Cobb-Douglas menunjukkan nilai koefisien determinasi $\left(\mathrm{R}^{2}\right)$ sebesar $81,74 \%$ yang artinya ialah bahwa goodness of fit antara data dan model ialah baik, dikarenakan nilai koefisien determinasi mendekati angka satu. Nilai $\mathrm{R}^{2}$ sebesar $81,74 \%$ berarti bahwa produksi kakao dipengaruhi oleh variabel-variabel luas lahan, tenaga kerja, pupuk Phonska, SP 36, dan Urea sebesar $81,74 \%$, dan sisanya $18,26 \%$ 
dipengaruhi oleh variabel-variabel lain yang tidak dimasukkan ke persamaan fungsi produksi. Hasil uji $\mathrm{F}$ memperlihatkan nilai $\mathrm{F}$ hitung sebesar 0,000 yang lebih kecil dibandingkan taraf signifikansi $(\alpha)$ 0,05, berarti bahwa input lahan, tenaga kerja, dan pupuk Phonska, SP 36, dan Urea secara bersama-sama mempengaruhi produksi kakao.

Berdasarkan Tabel 3, nilai signifikansi hitung untuk variabel luas lahan $\left(\mathrm{X}_{1}\right)$, pupuk SP $36\left(\mathrm{X}_{4}\right)$, dan pupuk Urea $\left(\mathrm{X}_{5}\right)$ lebih kecil dibandingkan taraf signifikansi 0,05 yang berarti bahwa koefisien regresi untuk ketiga variabel tersebut signifikan. Koefisien regresi untuk variabel tenaga kerja $\left(\mathrm{X}_{2}\right)$ dan pupuk Phonska $\left(\mathrm{X}_{3}\right)$ tidak signifikan karena nilainya lebih besar daripada signifikansi tetapan 0,05 . Dengan demikian maka persamaa regresi yang diperoleh melalui analisis fungsi produksi Cobb-Douglas ialah sebagai berikut :

$\mathrm{Y}=1,002253+0,445928 \log \mathrm{X}_{1}+0,302003 \log \mathrm{X}_{4}+0,350339 \log \mathrm{X}_{5}$

Variabel luas lahan memiliki elastisitas input 0,445928 di mana penggunaan lahan memberikan pengaruh positif terhadap produksi kakao. Setiap penambahan $1 \%$ luas lahan menyebabkan peningkatan produksi kakao $0,445928 \%$, sebaliknya jika lahan berkurang $1 \%$ maka produksi kakao menurun 0,445928 \%. Angka elastisitas input untuk luas lahan ialah yang paling besar dibandingkan variabel-variabel lainnya, menunjukkan bahwa luas lahan merupakan variabel yang paling responsif dalam mempengaruhi produksi kakao. Hal ini sejalan dengan penelitian Rinaldi et al (2013) yang menyatakan bahwa luas lahan berpengaruh positif terhadap produksi kakao. Jadi apabila petani ingin meningkatkan produksi kakao maka luas lahan yang diusahakan petani harus ditingkatkan, baik dengan cara membuka areal penanaman baru atau mengganti tanaman-tanaman perkebunan lainnya dengan tanaman kakao. Kenyataan di lapangan ialah bahwa petani kakao pada umumnya mengusahakan komoditas kakao dengan komoditas lainnya seperti pisang dengan pola tumpang sari. Diduga bahwa tingkat kepadatan jumlah tanaman yang dibudidayakan dalam satu areal menyebabkan menurunnya produksi kakao, selian meningkatnya serangan hama dan penyakit seperti PBK, busuk buah, dan mati pucuk karena kelembaban udara yang tinggi. Akan tetapi, peningkatan luas lahan memiliki konsekuensi peningkatan penggunaan input-input yang lain seperti tenaga kerja, pupuk, dan pestisida. Karena itu, peningkatan produksi melalui peningkatan luas lahan harus pula mempertimbangkan upah tenaga kerja, harga pupuk, dan pestisida sehingga tidak memberatkan petani dalam berusahatani kakao.

Variabel pupuk SP 36 memiliki elastisitas input sebesar 0,302003, yang berarti terdapat hubungan yang positif antara penggunaan pupuk SP 36 dengan produksi kakao. Penambahan penggunaan pupuk SP 36 sebesar $1 \%$ meningkatkan produksi kakao sebesar 0,302003\%, sebaliknya jika pupuk SP 36 dikurangi $1 \%$ maka produksi kakao akan turun sebesar 0,302003 $\%$. Hal ini sejalan dengan penelitian Gugere et al (2016) yang mengemukakan bahwa penambahan pupuk SP 36 pada lahan pertanian akan meningkatkan kandungan unsur hara fosfor yang berperan dalam merangsang pembungaan dan pembentukan buah serta mempercepat panen. Penambahan pupuk SP 36 memungkinkan untuk dilakukan oleh petani kakao di Desa Kele'i karena ditunjang oleh letak desa yang berdekatan dengan Kelurahan Tentena di Kecamatan Pamona Puselemba $( \pm 3 \mathrm{~km})$, yang memiliki kios-kios tani yang menjual pupuk dengan harga yang relatif terjangkau oleh petani. Rata-rata penggunaan pupuk SP 36 oleh petani ialah $40,84 \mathrm{~kg} / \mathrm{ha} /$ tahun, atau $136 \mathrm{gr} / \mathrm{pohon} /$ tahun pada populasi tanaman ratarata 300 pohon per hektar dengan jarak tanam yang umum digunakan yaitu $5 \times 6 \mathrm{~m}$. Rata-rata umur tanaman kakao milik petani ialah di atas 10 tahun. Jumlah pupuk SP 36 yang diberikan 
pada tanaman masih jauh di bawah rekomendasi yaitu sebesar $250 \mathrm{gr} /$ pohon/tahun untuk tanaman kakao berusia di atas 10 tahun, di mana pupuk diberikan 2 kali setahun dengan dosis $125 \mathrm{gr} /$ pohon (Cahyono, 2010).

Angka elastisitas input untuk variabel pupuk Urea ialah 0,350339, di mana penggunaan pupuk Urea berpengaruh secara positif terhadap produksi kakao. Penambahan pupuk Urea 1 $\%$ menyebabkan peningkatan produksi kakao 0,350339 \%, sebaliknya produksi kakao akan menurun $0,350339 \%$ jika penggunaan pupuk Urea dikurangi $1 \%$. Penelitian yang dilakukan oleh Gugere et al (2016) juga menunjukkan bahwa penggunaan pupuk Urea berpengaruh secara positif pada produksi kakao di Desa Tongoa Kecamatan Palolo Kabupaten Sigi, Sulawesi Tengah. Penambahan pupuk Urea pada lahan pertanian bertujuan meningkatkan kandungan unsur hara nitrogen dalam tanah yang sangat dibutuhkan oleh tanaman kakao untuk mempercepat tumbuhnya tanaman dan menambah besar ukuran biji kakao. Penambahan pupuk Urea dimungkinkan karena ketersediaan pupuk pada kios tani dengan harga yang terjangkau. Di samping itu, rata-rata penggunaan pupuk Urea sebesar $37,44 \mathrm{~kg} / \mathrm{ha} /$ tahun atau 124,8 gr/pohon/tahun masih di bawah rekomendasi sebesar $250 \mathrm{gr} /$ pohon/tahun.

\section{Skala Usahatani Kakao}

Skala usaha (return to scale) dari usahatani kakao di Desa Kele'i diperoleh dengan menjumlahkan koefisien regresi $b_{1}, b_{4}$ dan $b_{5}$ sehingga diperoleh angka 1,098 . Nilai RTS $>1$ mengindikasikan skala usaha meningkat (increasing return to scale), di mana tambahan output lebih besar daripada tambahan input. Jadi apabila penggunaan input lahan, pupuk SP 36, dan pupuk Urea ditingkatkan bersama-sama secara proporsional sebesar $1 \%$ maka produksi kakao akan meningkat sebesar 1,098\%. Sebaliknya jika input-input tersebut dikurangi bersama-sama sebesar $1 \%$ maka produksi kakao menurun $1,098 \%$. Berdasarkan nilai skala usaha, maka tambahan input secara serempak dan proporsional akan meningkatkan produksi, dan bila dikaitkan dengan angka-angka elastisitas input lahan, pupuk SP 36, dan pupuk Urea yang bernilai positif, maka penambahan penggunaan input masih dimungkinkan untuk meningkatkan produksi dan pendapatan petani kakao.

\section{Efisiensi Penggunaan Input pada Usahatani Kakao}

Efisiensi penggunaan input pada usahatani kakao di Desa Kele'i diketahui melalui rasio Nilai Produk Marginal (NPM) dan Harga Input (HI). Efisiensi tercapai apabila rasio NPM-HI bernilai satu, yang berarti bahwa penggunaan input mencapai tingkat yang optimal dan produsen memperoleh keuntungan yang maksimal. Hasil analisis efisiensi ditunjukkan pada tabel berikut.

Tabel 4. Efisiensi Penggunaan Input Usahatani Kakao di Desa Kele’i Tahun 2018

\begin{tabular}{lccccc}
\hline $\begin{array}{c}\text { Faktor } \\
\text { produksi }\end{array}$ & $\begin{array}{c}\text { Rata-rata } \\
\text { penggunaan } \\
\text { faktor } \\
\text { produksi }\end{array}$ & $\begin{array}{c}\text { Koefisien } \\
\text { regresi }\end{array}$ & NPM & HI & NPM/HI \\
\hline Lahan & 1,49 ha & 0,445928 & $3.112 .547,5$ & 500.000 & 6,225 \\
& & 0,302003 & $76.906,5$ & 2.300 & 33,44 \\
\hline
\end{tabular}




\begin{tabular}{|c|c|c|c|c|c|}
\hline Pupuk SP & 40,84 & & & & \\
\hline 36 & $\mathrm{~kg} / \mathrm{ha} /$ tahun & & & & \\
\hline & & 0,350339 & $97.308,9$ & 1.900 & 51,22 \\
\hline Pupuk & 37,44 & & & & \\
\hline Urea & $\mathrm{kg} / \mathrm{ha} /$ tahun & & & & \\
\hline
\end{tabular}

Sumber : Data primer (diolah), 2018

Tabel 3 menunjukkan rasio NPM/HI untuk variabel lahan sebesar 6,225 atau > 1, yang berarti bahwa penggunaan input lahan belum efisien dan masih dapat ditingkatkan luasannya. Nilai 6,225 berarti penambahan lahan sebesar 1 ha akan menyebabkan peningkatan penerimaan sebesar Rp 3.112.547,5 dan peningkatan biaya sebesar Rp 500.000. Tambahan biaya lebih kecil dibandingkan tambahan penerimaan, karena itu peningkatan produksi kakao melalui penambahan luas areal penanaman masih dimungkinkan. Walaupun demikian petani perlu mempertimbangkan ketersediaan modal untuk perluasan areal tanam, karena modal merupakan hambatan yang sering dialami petani dalam mengembangkan operasi usahatani. Peranan modal sangat penting, karena modal digunakan dalam penyediaan sarana produksi dan pengelolaan faktor-faktor produksi, termasuk pembukaan lahan baru atau pergantian jenis tanaman budidaya, yang bertujuan untuk meningkatkan pendapatan petani (Palunsu et al, 2014).

Rasio NPM/HI untuk variabel pupuk SP 36 ialah 33,44 atau > 1, yang artinya penggunaan pupuk SP 36 belum efisien dan penggunaannya masih dapat ditambahkan. Rasio sebesar 33,44 memperlihatkan bahwa penambahan pupuk SP 36 sebesar $1 \mathrm{~kg} / \mathrm{ha} / \mathrm{tahun}$ akan menyebabkan tambahan penerimaan sebesar Rp 76.906,5 dan tambahan biaya sebesar Rp 2.300. Sedangkan rasio NPM/HI untuk variabel pupuk Urea sebesar 51,22 juga bernilai $>1$, di mana penggunaan pupuk Urea belum efisien dan masih dapat ditingkatkan untuk memperbesar produksi. Rasio 51,22 memiliki arti penambahan pupuk Urea sebesar $1 \mathrm{~kg} / \mathrm{ha} / \mathrm{tahun}$ menyebabkan tambahan penerimaan sebesar 97.308,9 dan tambahan biaya sebesar Rp 1.900. Tambahan biaya pada penambahan penggunaan kedua jenis pupuk lebih kecil dibandingkan tambahan penerimaan, sehingga petani dapat mempertimbangkan penambahan penggunaan pupuk pada usahatani kakao yang dilakukannya. Produktivitas tanaman kakao pada petani yang menjadi responden penelitian ialah rata-rata sebesar $347 \mathrm{~kg} / \mathrm{ha}$ atau 0,347 ton/ha, lebih kecil dibandingkan produktivitas rata-rata Kabupaten Poso sebesar 0,82 ton/ha. Bila dikaitkan dengan perawatan tanaman, pemupukan yang dilakukan oleh petani tidak sesuai dengan dosis rekomendasi, terutama mengingat tanaman kakao di lokasi penelitian yang rata-rata berumur di atas 10 tahun dan memerlukan suplai hara sesuai kebutuhan umur tanaman. Mukminin et al (2017) mengemukakan bahwa produksi kakao yang dihasilkan sangat tergantung dari perawatan tanaman yang dilakukan oleh petani, termasuk dalam hal pemupukan. Jika perawatan terhadap tanaman dilakukan secara intensif maka produksi yang diperoleh juga besar.

Peningkatan produksi kakao dapat ditempuh melalui beberapa cara, di antaranya pemberian bimbingan teknis budidaya kepada petani, pemberian bantuan kredit sebagai insentif berproduksi untuk mengatasi keterbatasan modal, dan pemberian kebijakan input untuk menurunkan biaya input dan menambah nilai guna output. Hasil kajian Arfah et al (2017) memperlihatkan bahwa kenaikan harga pupuk Urea sebesar $33 \%$ dan pupuk SP 36 sebesar 29 $\%$ menyebabkan penurunan intensifikasi usahatani kakao di Provinsi Sulawesi Tengah dan 
semakin memperbesar penurunan keunggulan kompetitif komoditas kakao Sulawesi Tengah. Berdasarkan hasil analisis tersebut, diketahui bahwa harga pupuk bersubsidi merupakan salah satu faktor yang mempengaruhi daya saing kakao di Provinsi Sulawesi Tengah. Mekanisme penyaluran pupuk bersubsidi perlu diperbaiki dan dibarengi dengan usaha penyuluhan dan pendampingan yang intensif bagi petani sehingga tujuan peningkatan produksi dan pendapatan petani dapat tercapai.

\section{KESIMPULAN}

Luas lahan, pupuk SP 36, dan pupuk Urea berpengaruh secara positif dan signifikan terhadap produksi kakao. Skala usahatani kakao pada petani di Desa Kele'i Kecamatan Pamana Timur Kabupaten Poso ialah skala usaha meningkat (increasing return to scale), di mana tambahan input secara bersama akan meningkatkan produksi kakao. Penggunaan faktor produksi lahan, pupuk SP 36, dan pupuk Urea belum efisien, masih dapat ditambahkan untuk memperbesar produksi dan pendapatan petani kakao.

\section{REFERENSI}

Alkamalia A, Mawardati, dan Budi S. 2017. Analisis Pengaruh Lahan dan Tenaga Kerja Terhadap Produksi Kakao Perkebunan Rakyat di Provinsi Aceh. Jurnal Agrifo. 2 (2) : 56 - 61.

Antara M dan Effendy. 2009. Karakteristik Petani Kakao dan Produksinya di Kabupaten Parigi Moutong. Jurnal Agrisains. $10(1): 1-9$.

Arfah SYC, Harianto, dan Suharno. 2017. Daya Saing dan Peran Pemerintah dalam Meningkatkan Daya Saing Komoditi Kakao di Sulawesi Tengah. Buletin Ilmiah Litbang Perdagangan. $11(1): 69-96$.

BPS Poso. 2017. Kabupaten Poso dalam Angka 2017. Poso : Badan Pusat Statistik.

BPS Sulteng. 2012. Provinsi Sulawesi Tengah dalam Angka 2012. Palu : Badan Pusat Statistik.

BPS Sulteng. 2017. Sulawesi Tengah dalam Angka 2017. Palu : Badan Pusat Statistik.

Cahyono B. 2010. Sukses Bertanam Cokelat. Jakarta : Pustaka Mina.

Dewi N. 2012. Analisis Peluang Pilihan Kelembagaan Pemasaran Kakao di Provinsi Sulawesi Tengah. Indonesian Journal of Agricultural Economics. 3 (1) : 1 - 12.

Gugere JK, Antara M, dan Alam MN. 2016. Analisis Produksi dan Pendapatan Usahatani Kakao di Desa Tongoa Kecamatan Palolo Kabupaten Sigi. Jurnal Agroland. 23 (1) : $1-10$.

Hanafie R. 2010. Pengantar Ekonomi Pertanian. Yogyakarta : Penerbit Andi.

Mahabirama AK, Kuswanti H, Daryanto S, dan Winandi R. 2013. Analisis Efisiensi dan Pendapatan Usahatani Kedelai di Kabupaten Garut Provinsi Jawa Barat. Jurnal Aplikasi Manajemen. $11(2): 92-102$. 
Mukminin U, Murdy S, dan Kernalis S. 2017. Studi Agribisnis Kakao dalam Meningkatkan Pendapatan Usahatani Kakao di Kecamatan Kumpeh Kabupaten Muaro Jambi. Jurnal Ilmiah Sosio Ekonomika Bisnis. 20 (1) : $1-12$.

Palunsu C, Hadayani, dan Kalaba Y. 2014. Kelayakan Usahatani Kakao di Desa Sidondo IV Kecamatan Sigi Biromaru Kabupaten Sigi. Jurnal Agrotekbis. 2 (6) : 639 - 644.

Pradnyani CIAS dan Indrajaya IGB. 2014. Analisis Skala Ekonomi dan Efisiensi pada Usaha Perkebunan Kakao di Kecamatan Abiansemal Kabupaten Badung. E-Jurnal Ekonomi Pembangunan Universitas Udayana. 3 (9) : 403 - 412.

Rinaldi J, Fariyanti A, dan Jahroh S. 2013. Efisiensi Produksi Kakao Fermentasi pada Perkebunan Rakyat di Bali dengan Pendekatan Stochastic Frontier. Buletin RISTRI. 4 (1) : 81 - 90.

Rinaldi J, Fariyanti A, dan Jahroh S. 2013. Faktor-faktor yang Mempengaruhi Produksi Kakao pada Perkebunan Rakyat di Bali : Pendekatan Stochastic Frontier. Jurnal SEPA. $10(1): 47-54$.

Saptana. 2012. Konsep Efisiensi Usahatani Pangan dan Implikasinya Bagi Peningkatan Produktivitas. Forum Penelitian Agro Ekonomi. 30 (2) : 109 - 128.

Sarini. 2017. Efísiensi Penggunaan Input Produksi Kakao di Desa Dolago Kecamatan Parigi Selatan Kabupaten Parigi Moutong. Jurnal Mitra Sains. 5 (2) : $37-47$.

Tahir AG dan Fadwiwati AY. 2015. Analisis Finansial Usahatani Kakao Dalam Rangka Pengembangan Agribisnis Kakao di Kabupaten Luwu Sulawesi Selatan. Jurnal Agroteksos. $25(3): 187-195$.

Tangku F, Bakhs R, dan Tangkesalu D. 2015. Analisis Efisiensi Penggunaan Input Produksi Usahatani Kakao di Desa Kawende Kecamatan Poso Pesisir Utara Kabupaten Poso. Jurnal Agrotekbis. 3 (2) : $222-230$.

Yani D, Kasimin S, dan Indra. Analisis Efísiensi dan Faktor-faktor Yang Mempengaruhi Produksi Kakao di Kecamatan Bandar Baru Kabupaten Pidie Jaya. Jurnal Ilmiah Mahasiswa Pertanian Unsyiah. 2 (1) : $67-76$.

Yantu MR, Sisfahyuni, dan Sari N. 2011. Fungsi Produktivitas Usahatani Kakao Rakyat Provinsi Sulawesi Tengah. Jurnal Agroland. 18 (1) : $57-64$. 
